\title{
タイ国チャオプラヤー川流域内の大規模ダム 貯水池の新しい簡便な運用方法の提案と検証 PROPOSAL AND VERIFICATION OF A NEW SIMPLE RESERVOIR OPERATION FOR LARGE SCALE RESERVOIRS IN THE CHAO PHRAYA BASIN, THAILAND
}

\author{
道谷健太郎 $1 ・$ 手計太一2・只修一 3 ・スヴァンピモル ポンサコーン4 \\ Kentaro DOUTANI, Taichi TEBAKARI, Shuichi KURE and Pongthakorn SUVANPIMOL \\ 1学生会員 富山県立大学 工学部環境工学科（广939-0398 富山県射水市黒河5180） \\ 2正会員 工(博) 富山県立大学大学院准教授 工学研究科（干939-0398 富山県射水市黒河5180） \\ 3正会員 東北大学助教 災害科学国際研究所（干980-0845 宮城県仙台市青葉区荒巻字青葉468-1） \\ ${ }^{4}$ Royal Irrigation Department (811 Samsen Nakornchaisri, Dusit Bangkok 10300, Thailand)
}

The Chao Phraya River basin (CPRB) in Thailand had a massive flooding in 2011, which affected on not only Thai socio-economics but also global supply-chain of industrial production. The Thai government is planning watershed management for the CPRB. In order to propose a new reservoir operation system on science-based which can be easily put into practice, we studied a reservoir optimum operation for Bhumibol and Sirikit reservoirs in the CPRB. This paper proposed the new reservoir operation method that daily release discharge were decided by using the day before storage volume data. A usefulness of the reservoir operation method was verified using historical hydrological data. As a result, the proposed reservoir operation method could contribute stabilization of storage volume.

Key Words : 2011 flood, reservoir operation, watershed management, Chao Phraya River

\section{1. はじめに}

タイ国北部から中部を流れるチャオプラヤー川流域に おいて，2011年に発生した大洪水は同国のみならず世界 中の経済に大きな影響を与えた1)。同国における観測史 上最大の洪水であり，死者 813 名，被災者は900万人を超 えた．被害額は約3.5兆円と推計され，世界でも5番目の 経済被害額である 2 . 日系企業451社も被災し，サプライ チェーン全体に極めて大きな影響を与えた.

その後, 国際協力機構(JICA)や東京大学などが中心と なって，チャオプラヤー川流域の統合水資源管理に向け た支援が実施された. 現象理解といら面からは，佐山ら 3),4),5) は2011年洪水汇濫のメカニズム解明のために降雨流 出モデルと汇濫モデルを融合させて数值実験を利用して いる. Mateo et al. ${ }^{6}$ は，水資源モデルであるH08) と広域 氾濫モデルであるCaMa-Flood ${ }^{8)}$ をップリングさせ, チャオプラヤー川流域に適用し，洪水緩和対策への利用 可能性を示している. 一方で，上述した統合水資源管理 を運用するにはハード・ソフトともに整備が整うまでに 時間がかかる. そのために, 既存の水工施設を効率的,
最適に運用する方法を検討する必要がある.

小森ら ${ }^{9}$ はチャオプラヤー川流域上流に位置するプミ ポンダム貯水池とシリキットダム貯水池の操作方法につ いて検討している.この中で，貯水池への流入量の確率 評価を利用して, 利水容量を維持しながら治水操作する

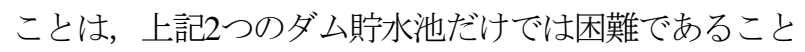
を示している. しかしながら, 抜本的な最適運用を提案 するまでに至っていないのが実情である.

ダム貯水池操作の最適運用方法として, 線形計画法や 非線形計画法を利用したものが多数研究されてきた ${ }^{10)}$. さらにそれらを応用した，ファジィ理論 ${ }^{11)}, \mathrm{AI}^{12) や}$ ニューラルネットワークなど数学を駆使した最適操作方 法も提案されてきた. 最近では, 気象モデルによる降雨 予測をダム操作に利用する研究も行われている ${ }^{13)}$. また, 長期的な貯水池運用を目的にグローバルな気象情報を利 用する方法も検討されている ${ }^{14)}$. 日本国内では, 先駆的 に事前放流方式の提案も行われている ${ }^{15}$.

これらの貯水池操作方法は，情報や技術，人材教育な どが整った国や地域のみで使うことができ，発展途上の 国々での利用は未だ困難である. 著者らのグループでは, 下坂ら ${ }^{15)}$ の事前放流ルールを参考に, 基礎的な検討を実 


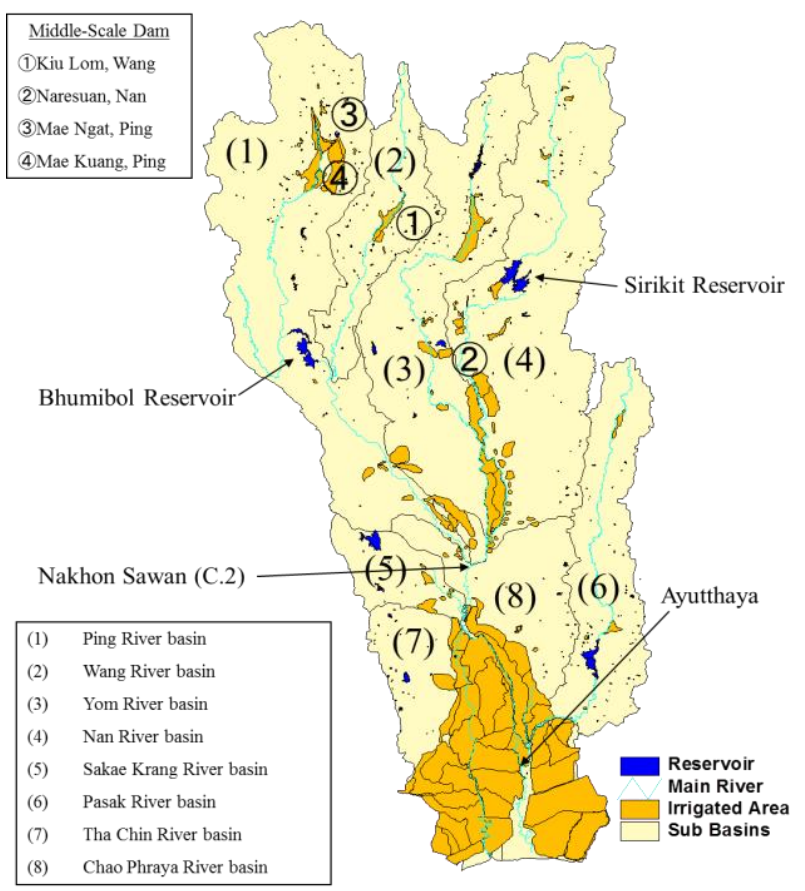

図-1 チャオプラヤー川流域.

施している ${ }^{16,17)}$.

そこで本研究では，タイ国チャオプラヤー川流域を対 象として，ダム貯水池運用を開始してから2012年までの 貯水池データだけを利用して, 利水と治水の両方に効果 が得られ，かつ現場での運用が簡便である方法を提案す る.

\section{2. チャオプラヤー川流域と大規模ダム貯水池}

本研究で対象とするチャオプラヤー川流域はタイ北部 から中央部にまたがり，同国最大の流域面積(157,925 $\left.\mathrm{km}^{2}\right)$ を持つ(図-1 $)^{18)}$. 北部の山岳域からPing川, Wang川, Yom川，Nan川の4支川が合流LChao Phraya川本川が始 まる，そして西部からSakae Krang川，下流では東側から Pasak川が流れ込み，一部はTha Chin川に分流し，最後に タイ湾へと流れる。流域は汇濫原, 下流域はデルタと いう構造をしている. また, タイ北部はほぼ頁岩, れき 岩, 砂岩等を基岩とした地質, バンコクを中心とする夕 イ中央平原は粘土で被われ，その他の平野，丘陵地は概 ねローム質の土で被われている. 対象流域の気候はアジ アモンスーンの影響を受け，雨期(5月から10月)と乾期 (11月から4月)の明膫な区別がある. 乾期のうちで特に3 月から4月は一年の中でも一番暑気が厳しい時期である. また乾期には60日から70日間の無降雨日が続くことがあ る. 一方, 雨期には激しいスコールに見舞われ, 各地で 洪水が発生している.

チャオプラヤー川流域内には，2014年現在，中・大規 模のダム貯水池が合わせて9つあり, その総貯水容量は
表-1プミポンダムとシリキットダムの諸元. ${ }^{19)}$

\begin{tabular}{|c|c|c|}
\hline 名称 & プミポンダム & シリキットダム \\
\hline 用途 & \begin{tabular}{|l} 
発電 \\
灌溉 \\
洪水調節
\end{tabular} & $\begin{array}{l}\text { 発電 } \\
\text { 灌溉 } \\
\text { 洪水調節 }\end{array}$ \\
\hline 管理 & タイ電力公社 & タイ電力公社 \\
\hline 河川 & ピン川 & ナン川 \\
\hline 集水面積 $\left(\mathrm{km}^{2}\right)$ & 26,386 & 13,130 \\
\hline 年間流入量 $\left(\times 10^{6} \mathrm{~m}^{3}\right)$ & $\begin{array}{r}5,814 \\
(1965-2012 \text { 年,平均 }) \\
\end{array}$ & $\begin{array}{r}5,772 \\
(1974-2012 \text { 年,平均) }\end{array}$ \\
\hline 年間流入量 $(\mathrm{mm})$ & 199.2 & 427.5 \\
\hline 最大貯水容量 $\left(\times 10^{6} \mathrm{~m}^{3}\right)$ & 13,462 & 10,508 \\
\hline 湛水面積 $\left(\mathrm{km}^{2}\right)$ & 316.0 & 260.0 \\
\hline ダム型式 & 重カアーチ式 & アースフィル式 \\
\hline
\end{tabular}

254億 $\mathrm{m}^{3}$ である1). その中で，プミポンダム貯水池は， 1957年に世界銀行の援助によってPing川上流に国王の名 を取り建設された, タイ国初の大規模かつ多目的ダムで ある. そして，次に，1961年，Nan川に同様規模の多目 的ダムを建設することが政府によって承認され，1977年， Nan川上流に女王の名を取ったSirikitダムが完成した. 両 ダムの主な特徽を表-1に示す ${ }^{19}$. 両ダムはEGAT

(Electricity Generating Authority of Thailand: タイ電力公社) が管理・運営するものであり, その主目的は発電である が，王立灌漞局との協議により灌溉用にも運用している. 運用目的は, 発電, 灌睡, 治水であり, その目的全てを 達成しなければタイ国の経済発展に大きな支障をきたす こととなる.

\section{3. ダム貯水池の現業の運用方法}

プミポンダム貯水池とシリキットダム貯水池は, 1996 年より月ごとに遵守すべき貯水量の上限值と下限值が定 められ，その時系列曲線がルールカーブと呼ばれる．放 流操作は, 貯水量がその範囲内に保たれるように行われ る.

2011年の大洪水の後, 両ダム貯水池ともにルールカー ブが変更された ${ }^{20)}$. 本稿では, 2011年以前のルールカー ブを旧ルールカーブ，2011年以降のルールカーブを新 ルールカーブとする. また, 上限值を示すルールカーブ をURC，下限值を示すルールカーブをLRCとする.

図-2はプミポンダム貯水池における新旧の貯水池操作 ルールカーブである. 新URC, 新LRCともに全体的に大 きく下げられた。 旧URCの最低值は7月の $10655 \times 10^{6} \mathrm{~m}^{3}$ であったが，新LRCの最低值は8月の $8917 \times 10^{6} \mathrm{~m}^{3}$ (下げ幅 $1738 \times 10^{6} \mathrm{~m}^{3}, 16 \%$ 減へへだられた。 旧LRCの最低值は7 月の $6791 \times 10^{6} \mathrm{~m}^{3}$ であったが，新LRCの最低值は6月の $5765 \times 10^{6} \mathrm{~m}^{3}$ (下げ幅 $1026 \times 10^{6} \mathrm{~m}^{3}, 15 \%$ 減)へ下げられた.

図-3はシリキットダム貯水池における新旧の貯水池操 作ルールカーブである. シリキットダム貯水池において もLRC，URCともに全体的に大きく下げられたことがわ かる. 旧LRCの最低值は7月の $5718 \times 10^{6} \mathrm{~m}^{3}$ であったが, 新LRCの最低值は6月の $4041 \times 10^{6} \mathrm{~m}^{3}$ (下げ幅 $1677 \times 10^{6} \mathrm{~m}^{3}$, 


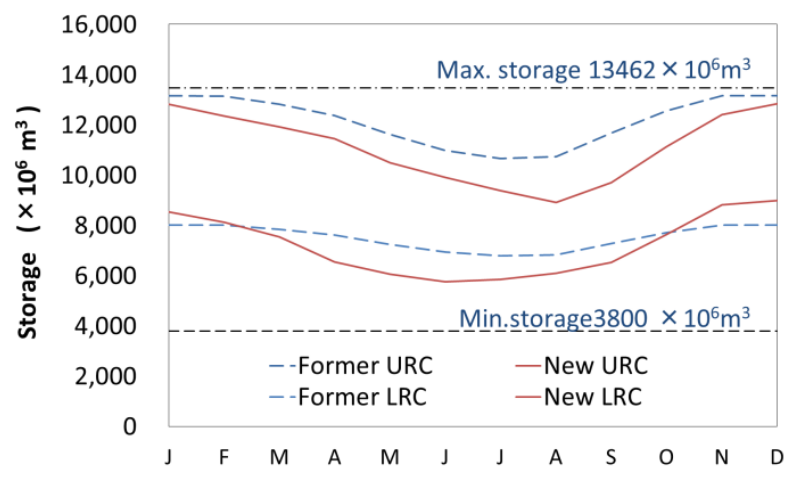

図-2 プミポンダム貯水池における新旧ダム貯水池操 作ルールカーブ.

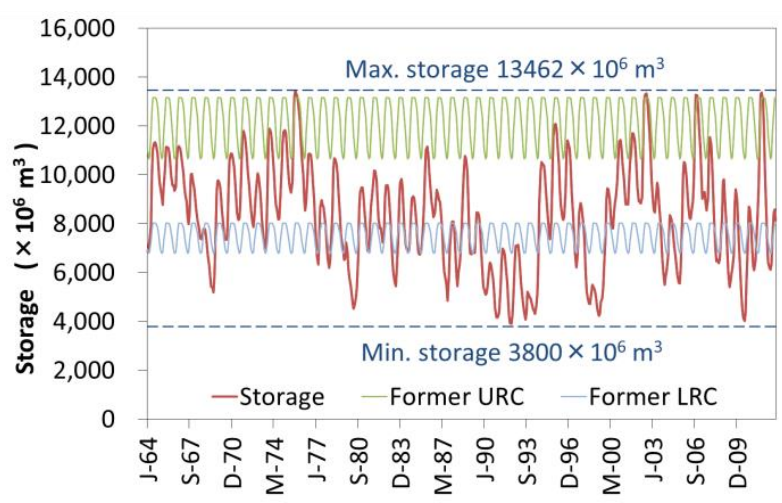

\section{図-4 プミポンダム貯水池における1964年〜2012年ま の月平均貯水量の時系列.}

$29 \%$ 減へ下げられた. LRCの最低值は新旧ともに7月で あるが旧LRCの $7208 \times 10^{6} \mathrm{~m}^{3}$ から，新LRCの $6155 \times 10^{6}$

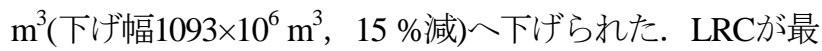
高值をとなる11月では旧LRCが7125 $\times 10^{6} \mathrm{~m}^{3}$ であったの に対し，新LRCは $6558 \times 10^{6} \mathrm{~m}^{3}$ まで下げられた.

このように，全体的にルールカーブを引き下げ，雨期 終盤前に上下限幅を絞ることによって，洪水に対して安 全側に操作するような運用方法になったと解釈できる.

図-4はプミポンダム貯水池における1964年〜2012年ま での月平均貯水量の時系列である. 図中の緑色と水色の 実線は，旧URC，旧LRCをそれぞれ示している，ルール カーブを用いた運用を開始した1996年から2011年の16年 間(192ヶ月)のうち，月平均貯水量が旧LRCを下回った月 は68回(35.4\%)であった. 1964年〜1995年の間(379ケ月) にも旧LRCを適用したと仮定すると，月平均貯水量が旧 LRCを下回った月は191回(50.4\%)であった．また，1989 〜95年，1998〜2000年においては長期に渡り貯水量が旧 LRCを下回っている. 一方で1975，2002，2006，2011年 には雨期の終盤に貯水量が最大貯水量の $98 \%$ \%回って いる.

図-5はシリキットダム貯水池における1974年〜2012年 までの月平均貯水量の時系列である.ルールカーブを用 いた運用を開始した1996年から2011年の16年間のうち， 月平均貯水量が旧LRCを下回った月は95回(49.5\%)で

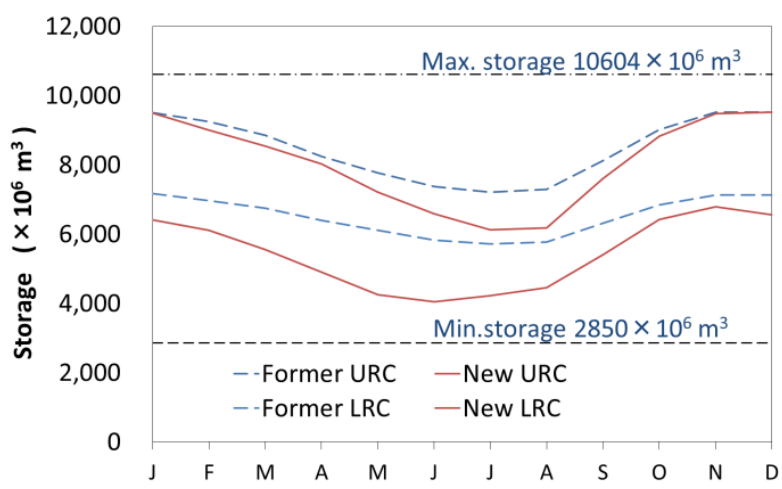

図-3 シリキットダム貯水池における新旧ダム貯水池 操作ルールカーブ.

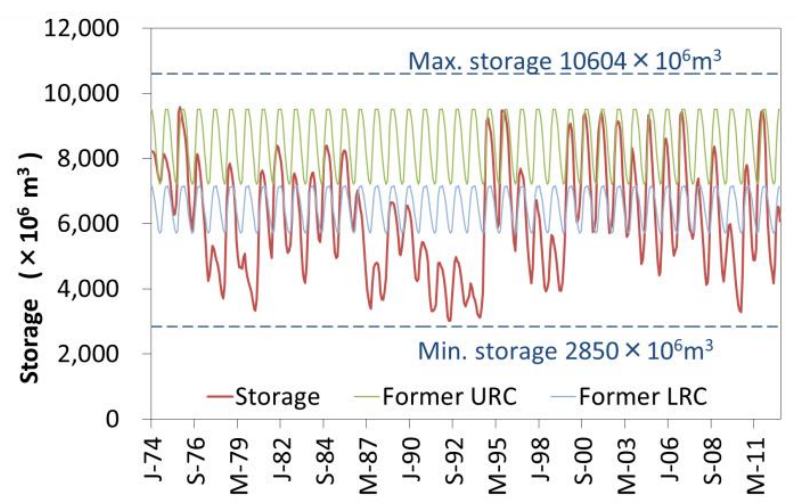

図-5 シリキットダム貯水池における1964年〜2012年ま での月平均貯水量の時系列.

あった．1974年～1995年の間(264ヶ月)にも旧LRCを適用 したと仮定すると，月平均貯水量が旧LRCを下回った月 は166回 (62.9\%)であった. 全体の50〜60\%は, 貯水量 が非常に少ない状態であったことがうかがえる. また, シリキットダム貯水池においても1987〜95年，1998〜 2000年の間，長期に渡り連続的に貯水量が旧LRCを下 回っている. なお，1975年9月末から10月のはじめに記 録した $9642.6 \times 10^{6} \mathrm{~m}^{3}$ (最大貯水量の $\left.91.0 \%\right)$ が貯水量の過 去最高值である.

\section{4. 新しい簡便な運用方法の提案とその検証}

\section{（1）新しい運用方法}

前述したように，現業の貯水池操作規程は，貯水量を ULCとLRCの間に保つように貯水操作寸るものである. 発電のための最低放流量や灌激用の放流量が規定され， さらに乾期を迎える12月31日時点で満水に近い貯水量が 望まれているため, 非常に難しい運用を強いられている のが実情である.

そこで, 本研究では既存のルールカーブを利用して, 前日貯水量に応じて日放流量を決定する極めてシンプル な運用方法を提案する. その方法を以下に示す.

まず，一日ごとの日放流量を前日の貯水量から決定す 


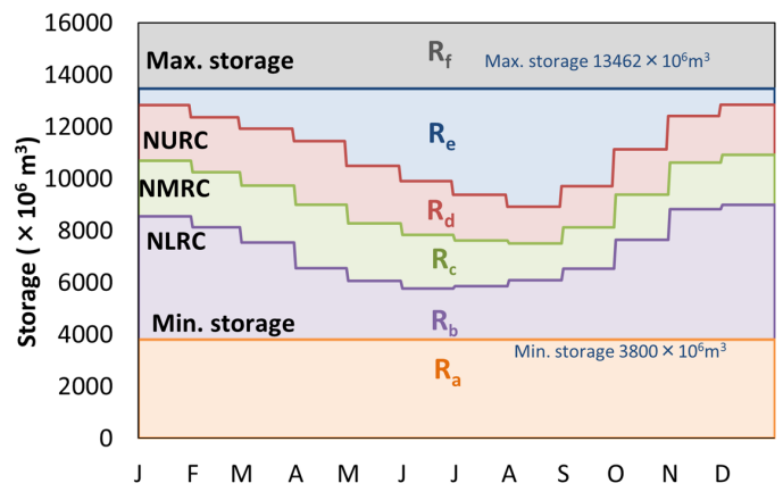

図-6 プミポンダム貯水池における貯水量と各閾値の時 系列.

表-2 ケースごとの放流量 (単位: $\mathrm{m}^{3} / \mathrm{s}$ )

\begin{tabular}{|l|r|r|r|l|l|l|}
\hline & $R_{a}$ & \multicolumn{1}{c|}{$R_{b}$} & \multicolumn{1}{c|}{$R_{c}$} & $R_{d}$ & $R_{e}$ & $R_{f}$ \\
\hline Case. 1 & 0 & 160 & 160 & 300 & 450 & 600 \\
\hline Case. 2 & 0 & 80 & 160 & 300 & 450 & 600 \\
\hline Case. 3 & 0 & 80 & 80 & 300 & 450 & 600 \\
\hline
\end{tabular}

る. 日貯水量は以下のように定義する.

$S_{i}=S_{i-1}+Q_{i}-R_{i}-E_{i}$

ここで, $S_{i}: i$ 日目の貯水量, $\mathrm{S}_{i-1}: i-1$ 日目の貯水量, $Q_{i}$ : $i$ 日目の日流入量, $\mathrm{R}_{i}: i$ 日目の日放流量, $\mathrm{E}_{i}: i$ 日目の日蒸 発量である. なお， $S_{0}$ はプミポンダム貯水池においては 1964年6月1日，シリキットダム貯水池においては1974年 1月1日の貯水量とした。次に，日放流量 $R_{i}$ を決定するた め，新ルールカーブを基に以下に示す5つの閾值を設定 した.ここで, Min.S : 最低貯水量, $N L R C$ : 新LRC, $N M R C$ : 新LRC, URCの中間值, $N U R C$ : 新 $\mathrm{URC}$, $\operatorname{Max} . S$ : 最大貯水量である. これらの閾值は操作の簡便 性のために，日ごとに設定するのではなく月一定に設定 した值を用いる. 最後に，日放流量 $R_{i}$ を決定するために 新ルールカーブをもとに以下の様に $R_{a} \sim R_{f}$ の6段階に決 定する. 以上を図-6, 図-7に図示する.

i) $S_{i}<$ Min. $S$ のとき $R_{i+1}=R_{a}$

ii) Min. $S \leq S_{i}<N L R C$ とき $R_{i+l}=R_{b}$

iii) $N L R C \leq S_{i}<N M R C$ のき $R_{i+1}=R_{c}$

iv) $N M R C \leq S_{i}<N U R C$ とき $R_{i+1}=R_{d}$

v) $N U R C \leq S_{i}<\operatorname{Max} . S$ のき $R_{i+1}=R_{e}$

vi) $\operatorname{Max} . S \leq S_{i}$ のとき $R_{i+1}=R_{f}$

\section{（2）新しい運用方法の検証方法}

本項では，本稿で提案した放流操作を過去の貯水池 データに適用してその妥当性を検証した．解析期間は， プミポンダム貯水池では1964年6月1日～2012年12月31日， シリキットダム貯水池では1974年1月1日～2012年12月31 日である。

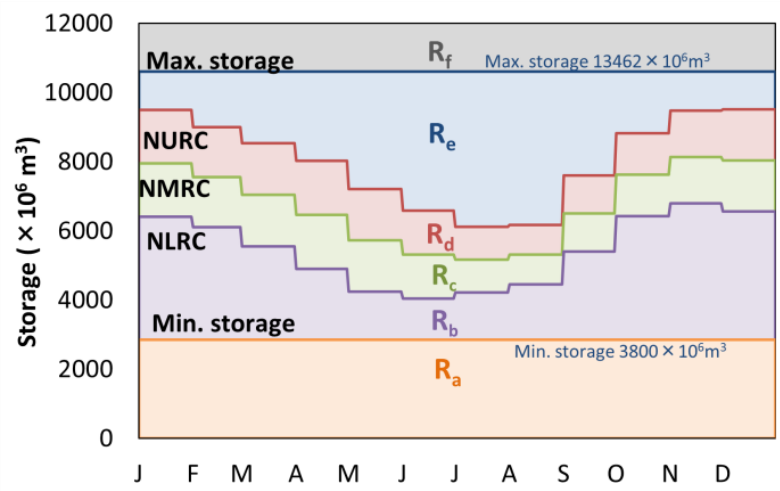

図-7 シリキットダム貯水池における貯水量と各閾値の 時系列.

本稿では規定する放流量の妥当性を評価するために, いくつかの放流量パターンを検証した．各ケースにおけ る放流量 $R_{a} \sim R_{f}$ を表-2に示守.

$R_{a}$ は貯水量が最低貯水量を下回っている場合の放流量 であるから全てのケースにおいて $0 \mathrm{~m}^{3} / \mathrm{s}$ した。

プミポンダム貯水池では，乾期の操作規定の中で，放 流量が $160 \mathrm{~m}^{3} / \mathrm{s}$ を下回ってはならないと定められている 19). よって, Case. 1においては, $R_{b}, R_{c}$ の值を $160 \mathrm{~m}^{3} / \mathrm{s}$ と した. 下限の許容量を検証するため, Case. 2では $R_{b}$ を,

Case. 3 では $R_{b}$ と $R_{c}$ を $80 \mathrm{~m}^{3} / \mathrm{s}$ とた. プミポンダム貯水池 では放流量が $750 \mathrm{~m}^{3} / \mathrm{s}$ (日放流量 6500 万 $\mathrm{m}^{3}$ )を超過すると 下流で洪水汇濫のリスクが高まるため, 通常は日放流量 が4000万 $\mathrm{m}^{3}\left(\right.$ 約 $\left.463 \mathrm{~m}^{3} / \mathrm{s}\right)$ を超える放流は行わないことに なっている22). またプミポンダム貯水池の発電最大放流 量は日量6000万 $\mathrm{m}^{3}\left(\right.$ 約694 $\left.\mathrm{m}^{3} / \mathrm{s}\right)$ である ${ }^{22)}$. これら基に, 全てのケースにおいて $R_{d} ， R_{e} ， R_{f}$ をそれぞれ $300 \mathrm{~m}^{3} / \mathrm{s}$, $450 \mathrm{~m}^{3} / \mathrm{s}, 600 \mathrm{~m}^{3} / \mathrm{s}$ と設定した. これらの条件で操作した 場合の日貯水量，日放流量を計算した.

シリキットダム貯水池においても，表-2と同様の值を 用いた.シリキットダム貯水池については，詳細な放流 ルールが公表されていないため, 便宜上, プミポンダム 貯水池と同様の值とした。

\section{（3）新しい運用方法の検証結果}

\section{a）プミポンダム貯水池における検証結果}

図-8は表-2のCase. 1〜3を適用した場合のプミポンダ 么貯水池の貯水量の計算結果を表している。図中の死色 の実線は，実際のプミポンダム貯水池の貯水量を示して いる，前述したような，貯水量が長期に渡って旧LRCを 下回るような期間(1989～95年，1998～2000年)において， Case. 1は実際の貯水量よりも貯水量が小さく, Case. 2, Case. 3では貯水量が大きく算出された. Case. 1 とCase. 2 の違いは，貯水量がMin. $S \leq S_{i}<N L R C$ となる時の放流量 $R_{b}$ の值である。したがって，貯水量が $N L R C$ を下回る期 間に $160 \mathrm{~m}^{3} / \mathrm{s}$ の放流をしなければならないことが，連続 した渇水の要因の一つであると考えられる。また同期間 


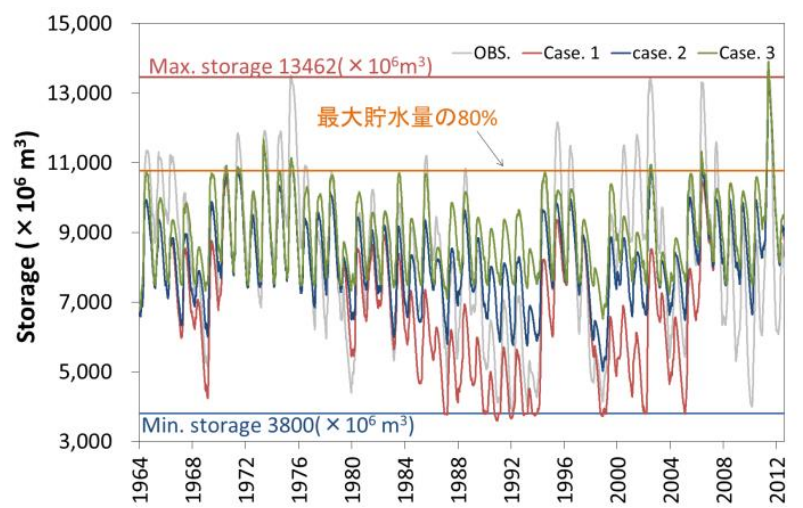

図-8 プミポンダム貯水池における各ケースの検証結果 (各ケースの貯水量と実際の貯水量).

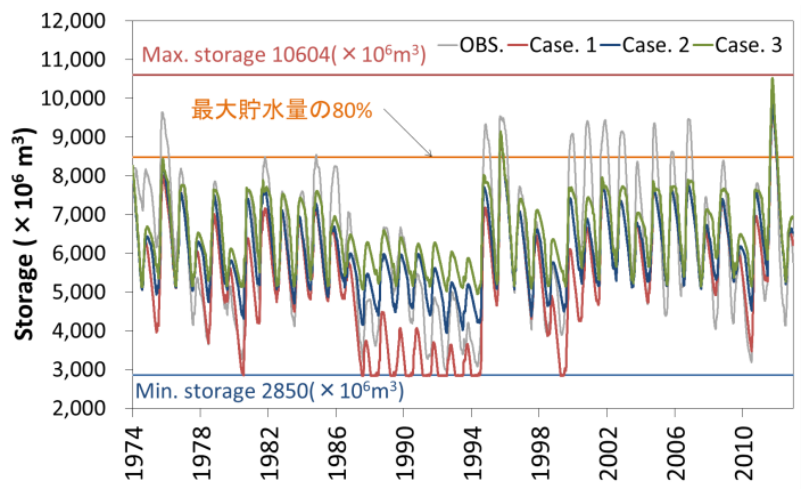

図-10 シリキットダム貯水池における各ケースの検証結果 (各ケースの貯水量と実際の貯水量).

の放流量を $80 \mathrm{~m}^{3} / \mathrm{s}$ まで絞れば長期に亘る貯水量の低下を 抑制できる可能性がある。しかし，発電や灌瀄のために， 最低放流量を小さくすることは容易でない.

一方，実際の貯水量は1975，2002，2006，2011年に最 大貯水量やその付近にまで到達している. しかし本提案 手法では，全てのケースにおいて，2011年の貯水量のみ が最大貯水量を超過するものの，それ以外の年では貯水 量が最大貯水量の $90 \%$ を超過することはなかった.

図-9は図-8における12月31日時点の貯水量を示したも のである. 灰色の点は各年12月31日における実際の貯水 量を表している．また，赤，青の破線はそれぞれ12月の 新URC・LRCを示し, オレンジの実線は最大貯水量の $80 \%\left(10770 \times 10^{6} \mathrm{~m}^{3}\right)$ を示している. Case. 1では新LRCを 下回った年が26年 $(53.1 \%)$ あた. さらに，14年(28.6\%) は貯水量が新URCの $80 \%$ に満たなかった. Case. 2でも新 LRCを下回る年が18年(36.7\%)であったが，新URCの $80 \%$ に満たなかった年は2年(4.1\%)にすぎない. Case. 3 においては，新LRCを下回った年が6年(12.2\%)あったが, 新URCの $80 \%$ 以上であった年はなかった. プミポンダ 么貯水池は, 平均約1.6年分の流入量を貯水する必要が あり，渴水が2年以上継続すると貯水量の回復には極め て長い時間がかかる.

ここで，翌年の乾期に安心して灌激農業が実施できる 重要な指標である最大貯水量の $80 \%$ という基準を用いて 貯水量を検討する. 各ケースの結果を最大貯水量の $80 \%$

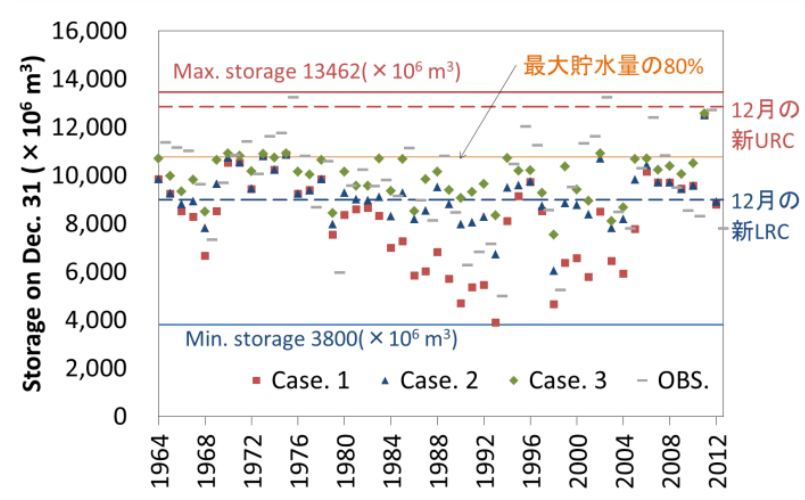

図-9 プミポンダム貯水池における各ケースの検証結果 (各年12月31日時点での貯水量).

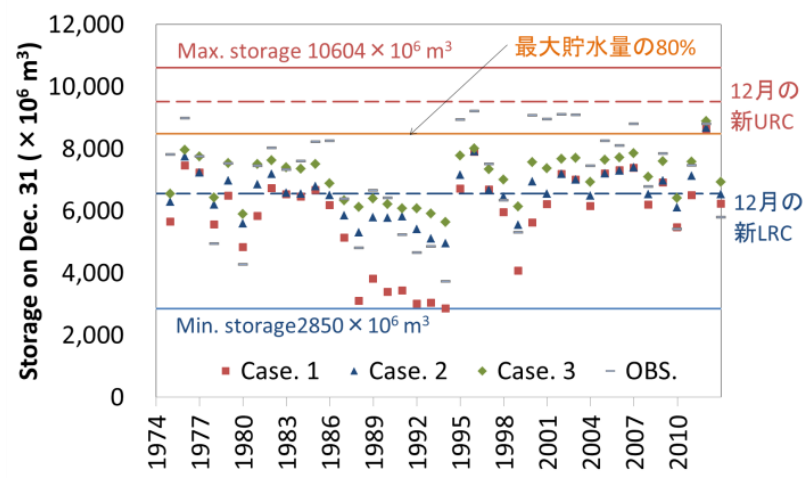

図-11 プミポンダム貯水池における各ケースの検証結果 (各年12月31日時点での貯水量).

と比較すると, Case. 1, Case. 2では2011年以外の全て の年で最大貯水量の $80 \%$ に達しておらず，Case. 3におい ては49年中6年(12.2\%)のみである. 以上から，本提案手 法では，洪水の抑制に大きな効果が認められる一方， 12 月 31 日時点の貯水量を最大貯水量の $80 \%$ まで貯水するこ とは難しい.

\section{b）シリキットダム貯水池における検証結果}

図-10は表-2のCase. 1〜3を適用した場合のシリキット ダム貯水池の貯水量の計算結果を表している. 図中の灰 色の実線は，実際のシリキットダム貯水池の貯水量を示 している. 前述した貯水量が長期に渡って旧LRCを下回 るような期間(1987～95年，1998～2000年)において，

Case. 1は貯水量が小さく, Case. 2 とCase. 3 では実際の貯 水量よりも貯水量が大きくなる。 したがって, シリキッ トダム貯水池においてもプミポンダム同様に貯水量が $N L R C$ を下回る期間の放流量を $80 \mathrm{~m}^{3} / \mathrm{s}$ まで絞れば長期に 亘る貯水量の低下を抑制できる可能性がある.

図-11は図-10における12月31日時点の貯水量を示した ものである. 灰色の点は各年12月31日における実際の貯 水量を表している．また，赤，青の破線はそれぞれ12月 の新URC・LRCを示し，オレンジの実線は最大貯水量の $80 \%\left(10770 \times 10^{6} \mathrm{~m}^{3}\right)$ を示している. Case. 1では新LRCを 下回った年が 25 年 $(64.1 \%)$ あった。さらに 10 年 $(25.6 \%)$ は新URCの80\%に満たなかった。 またCase. 2では, 新 
LRCを下回る年が20年 $(51.2 \%)$, 新URCの $80 \%$ \%満たな かった年は2年(5.1\%)であり, Case. 1に比べ少ない. Case. 3においては，新LRCを下回った年が13年(33.3\%) あったが，新URCの $80 \%$ に満たなかった年はなかった。 各ケースの結果を最大貯水量の $80 \%$ と比較すると，全て のケースにおいて2011年以外の全ての年で最大貯水量の $80 \%$ に達していない. 一方，実際の貯水量は，39年中9 年 $(23.1 \%)$ で最大貯水量の $80 \%$ に達している. シリキッ トダム貯水池においても，本提案の手法では，洪水の抑 制には大きな効果が認められる一方，12月31日時点の貯 水量を最大貯水量の $80 \%$ まで貯水することは難しい.

\section{5. 結論}

本研究では, タイ国チャオプラヤー川流域を対象とし て, 利水と治水の両方に効果が得られ，かつ現場での運 用が簡便である貯水池操作方法を提案することを目的と した. 本研究で提案した操作方法は, 前日貯水量に応じ て日放流量を決定する極めてシンプルな運用方法である。 また, 本研究のもう一つの特徵は, 提案した放流操作を 過去に貯水池運用された全期間を通して適用することで, 長期間の貯水池運用の妥当性を検証したことである.

本研究の結果, 本提案手法は2 $20 大$ 大規模ダム貯水池 において, 貯水量を安定してルールカーブ内に保つ事が できた. 貯水量が安定することは長期的な渴水や頻度の 高い洪水の抑制に繋がる. しかし，2011年のような50〜 100年規模の大洪水に対応できていない. また，本稿で は貯水量によって運用法を評価したが，下流域への影響 は十分に評価できてはいない，今後は著者らのグループ が既にチャオプラヤー川に実装している降雨流出モデル を用いるとともに，下流域の渇水時の水需要量を算定す ることで, 本研究で提案する放流を行った場合の, 下流 域での洪水・渴水状況等を詳細に評価していきたい.

本稿で提案した運用法では貯水量のみから放流量を決 定したが，今後はより現実に則した提案にするために, 貯水量の上限の設定や雨期・乾期別の操作方法の導入を 行う必要がある.

\section{参考文献}

1) 手計太一: 2011 年チャオプラヤー川大洪水一被害拡大の要 因と今後の課題一, 河川災害に関するシンポジウム, 2012.

2) Komori, D., et al.: Characteristics of the 2011 Chao Phraya River flood in Central Thailand, Hydrological Research Letters, Vol. 6, pp.41-46, 2012.

3) 佐山敬洋, 建部祐哉, 藤岡奨, 牛山朋來, 萬矢敦啓, 田中茂 信: 2011 年タイ洪水を対象にした緊急対応の降雨流出汇濫 予測, 土木学会論文集 B1(水工学), Vol. 69, No. 1, p. 14-29, 2013.

4) 佐山敬洋, 建部祐哉, 藤岡奨, 牛山朋來, 田中茂信: 大規模
洪水氾濫の時空間起源分析に関する研究, 土木学会論文集 B1(水工学), Vol. 69, No. 4, I_463-I_481, 2013.

5) 建部祐哉, 佐山敬洋, 牛山朋來, 藤岡奨, 田中茂信: チャオ プラヤ川流域における長期降雨流出汇濫解析, 土木学会論 文集 B1(水工学), Vol. 69, No. 4, I_457-I_462, 2013.

6) Mateo, C. M. R., et al.: A simulation study on modifying reservoir operation rules: tradeoffs between flood mitigation and water supply, Proceedings of H09, IAHS-IAPSO-IASPEI Assembly, IAHS Publ. 362, 2013.

7) Hanasaki, N., et al:: An integrated model for the assessment of global water resources - Part 1: Model description and input meteorological forcing, Hydrology and Earth System Sciences, 12, 1007-1025, 2008.

8) Yamazaki, D., Kanae, S., Kim, H. and Oki, T.: A physically based description of floodplain inundation dynamics in a global river routing model, Water Resources Research, 47, W04501, 10.1029/2010WR009726, 2011.

9) 小森大輔ら: 確率評価を用いた洪水緩和と水資源確保を考 慮した季節スケールでの大ダム貯水池操作の検討, 第 21 回 地球環境シンポジウム講演集, pp.115-125, 2013.

10)竹内邦良: 貯水量の累加損失係数を用いた貯水池群の最適 操作手法, 土木学会論文報告集, No.222, pp.93-103, 1974.

11)小尻利治, 池淵周一, 十合貴弘: ファジィ制御によるダム貯 水池の実時間操作に関する研究, 京都大学防災研究所年報, 第30 号, B-2, pp.323-339, 1987.

12)池淵周一: 水資源システムにおける $\mathrm{AI}$ 利用, 水文・水資源 のための AI 技術の利用に関する講座,pp.1-15, 1991.

13)三石真也，角哲也，尾関敏久: WRF による降雨予測を活用し たダム操作に関する検討, ダム工学, 20(2), pp.94-104, 2010.

14)野原大督, 三木博子, 堀智晴: 長期貯水池操作のための多様 な全球気象情報の利用可能性, 京都大学防災研究所年報, 第 54 号, B, pp.699-709, 2011.

15)下坂将史, 点修一, 戸谷英雄, 山田正, 吉川秀夫: 既存ダム 群の洪水調節機能向上のための新しい放流方法の提案, 水 工学論文集, 第 52 巻, pp.511-516, 2008.

16)小川厚次,手計太一,吳修 : タイ国における大規模ダム貯水 池の最適運用法に関する基礎的検討,水文・水資源学会 2013 年研究発表会要旨集,pp.78-79, 2013.

17)道谷健太郎ら : タイ国チャオプラヤー川流域内における大 規模ダム貯水池操作に関する基礎的検討,第 22 回地球環境 シンポジウム講演集,pp.181-184, 2014.

18)手計太一,吉谷純一 : 大ダム建設が流況に与えた影響一タイ 王国・Chao Phraya 川流域を対象として一,水文・水資源学会 誌,第 18 巻 3 号, pp.281-292, 2005.

19)手計太一 : タイ王国の水資源開発一歴代為政者たちの水資 源政策,現代図書, $224 \mathrm{p}, 2008$.

20)玉田芳史,星川圭介,船津鶴代 : タイ2011年大洪水一その記録 と教訓一アジア経済研究所,206p, 2013. 